\title{
Pyrethroid Resistance Monitoring in Culex pipiens Mosquito Populations from Three Egyptian Governorates
}

Tageldin $^{1}$, R.A.; Zayed ${ }^{2}$, A.; Abd-EI-Samie², E.M.; Mahmoud ${ }^{1}$, H.I. and Zayed ${ }^{1}$, A.B.

Received: 11/04/2018

Accepted: 02/07/2018

E.mail:Reham_abulwafa@yahoo.com

\section{KEYWORDS}

\section{Insecticide}

Resistance, Culex

Pipiens, Monitoring,

Pyrethroid.

\section{ABSTRACT}

Insecticide resistance monitoring of mosquito field populations is a crucial for guide and select the rational application of this insecticide. Both, levels and mechanisms of resistance are important to select efficient insecticides for the control of disease vectors. Culex pipiens mosquitoes collected from three different Governorates in Egypt (El-Fayoum, Menofia and Giza), were tested for insecticides susceptibility against Lambda-cyhalothrin and DDT. The results showed high resistance to the tested insecticides among Menofia and Giza collected populations, whereas El-Fayoum population showed low level of resistance. a great precaution should be considered about the type of control measures in these areas, when using the same insecticide. The presented output is alarming to health sectors and vector control decision makers. Mosquito control programs may need considering alternative insecticide classes for control of C. pipiens in the monitored areas.

1. Faculty of Science, Al Azhar University (Branch of Girls), Cairo, Egypt.

2. Faculty of Science, Cairo University, Giza, Egypt. 


\section{INTRODUCTION}

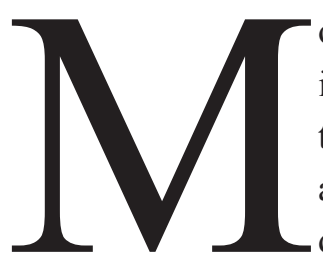

osquitoes are among the most important insect vectors that transmit numerous widespread and devastating insect-borne diseases. Culex species (Diptera: Culicidae) are the most widely distributed mosquitoes in the world. Culex pipiens complex has spread from its origin in Africa to tropical and temperate climate zones in all continents. They transmit numerous serious pathogens of diseases, such as lymphatic filariasis, Rift Valley Fever, West Nile encephalitis, St. Louis encephalitis, Venezuelan equine encephalitis and Japanese encephalitis and eastern equine encephalitis (CDC, 2002; Cui et al., 2006; Kasai et al., 2008 and Zhang et al., 2012). Around 1.4 billion people in 73 countries are presently threatened by lymphatic filariasis. In Egypt, $C$. pipiens is the most widespread mosquito species in urban and rural areas and causes a human health risk (Zahran and Abdelgaleil, 2011).

Chemical control, since the 1950s, has been the main effective method to reduce the vectors disease population (Hemingway et al., 2006). The main groups of chemical insecticides are the most recommended for mosquito vector control programs (organochlorines, organophosphates, carbamates, and pyrethroids). Pyrethroids are the main groups of insecticide used for vector control, represent about $25 \%$ of the world insecticide market, because they are fast acting, safe (have low toxicity) to mammals and birds. Also, pyrethroids increasingly deployed in indoor residual spraying (IRS) programs especially in Africa (Zaim et al., 2000; Katsuda et al., 2008; WHO, 2009 b). These insecticides are widely used in both agriculture and public health pesticides (WHO, 2009 a \& b). The continuous use of one group of insecticides for long period in the same area may cause, under insecticide selection, development of insecticide resistance in most of species including C. pipiens. The World Health Organization described insecticide resistance as "The development of an ability in a strain of an organism to tolerate doses of toxicants, which would prove lethal to a majority of individuals in a normal (susceptible) population of the same species". Recently, the insecticide resistance is becoming a major problem in the control of vector-borne diseases and public health concern (Rivero et al., 2010). Lambda-cyhalothrin, is now one of the most important synthetic pyrethroid insecticide that kills insects by stimulating their nervous system (a similar mode of action to DDT), also is commonly used in bed net impregnation and IRS to help control the transmission of insect-borne diseases (Tungu et al., 2010).

Detecting susceptibility changes in vector populations through bioassay are the first step to recognize the potential problem. The aim of this study is to identify the susceptibility status of $C$. pipiens populations from different Governorates of Egypt to pyrethroid and DDT to provide public health sectors crucial information to support designing an effective and successful mosquito control program.

\section{MATERIALS AND METHODS}

\section{Test insects}

Culex pipiens mosquito populations were reared after the technique mentioned by Chapman and Barr (1969). The reference strain used in this study was $C$. pipiens susceptible strain maintained at $\mathrm{Na}-$ val Medical Research Unit No. 3 (NAMRU 3) insectary under standard conditions $\left(26-28^{\circ} \mathrm{C}, 12 \mathrm{~h}: 12\right.$ $\mathrm{h}$ light/dark period, $70-80 \%$ relative humidity). This strain has not been exposed to any insecticide or biological control agent for longer than 35 years (Zayed et al., 2006).

Larvae of mosquito populations were collected from three different sites across, Menofia (Gazour, Quesna district), Giza (Mansouria canal) and ElFayoum (Sinnuris) Governorates (Fig. 1). The collection was carried out during November 2013- till 
November 2014. Collected mosquito larvae were morphologically identified to species level using the keyset by Harbach (1985). Culex pipiens larvae were separated in plastic trays $(27 \times 16 \times 6.5$ $\mathrm{cm})$ filled with tap water and fed with fish food until adult emergence. Adults were released in screened net cages $(12 \times 12 \times 12 \mathrm{~cm})$, supplied with $10 \%$ sucrose solution and fed on adult pigeon's blood. All tests were conducted using the progeny of the F1 generation.

Animal used for blood feeding process was conducted according to the guidelines of Institutional Animal Care and Use Committee IACUC (protocol No. 14-01).

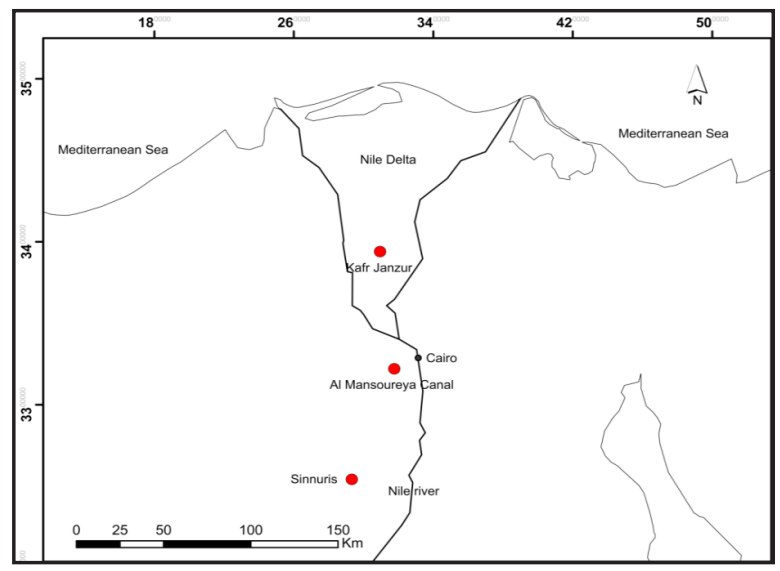

Fig. (1): Map of Egypt showing the sites where populations of Culex pipiens were collected.

\section{Insecticide susceptibility tests}

The susceptibility status of adult mosquitoes was determined according to WHO standard procedure (WHO, 1981a, 1998 and 2013). Insecticides used, $0.05 \%$ Lambda-cyhalothrin and 4\% DDT, were obtained from WHO Collaborating Centre, Malaysia in the form of insecticide impregnated papers. Batches of 20-25 healthy unfed adult female, aged 3-5 days were exposed to insecticide impregnated papers for $1 \mathrm{~h}$ (diagnostic concentrations) of $0.05 \%$ lambdacyhalothrin and 4\% DDT. During exposure, the knocked down individuals were counted every 15 minutes. After the exposure time, the tested mosqui- toes were transferred to the holding tubes, provided with cotton pads soaked in $10 \%$ sugar solution and mortality was recorded 24 hours post-exposure. The laboratory susceptible colony strain of $C$. pipiens was used as a reference to ensure the reliability of impregnated papers. Four replicates were conducted for each insecticide and control. All susceptibility tests were carried out at $26-28^{\circ} \mathrm{C}$ and $70-80 \%$ relative humidity.

\section{Statistical analyses}

Susceptibility test data were analyzed according to WHO criteria (Davidson and Zahar, 1973 \& WHO, 2013) as follows; mortality in the range between $98-100 \%$ indicates susceptibility; while 80 $98 \%$ mortality indicated possibility of resistance that needed further confirmation, and $<80 \%$ mortality indicated resistance.

Mortality data were subjected to one-way analysis of variance, and the Tukey honestly significant difference test $(\mathrm{P}<0.05)$ multiple comparison procedure was used to separate significantly different means (SPSS Statistics, 2008).

\section{RESULTS}

\section{Insecticide resistance status}

A field population of mosquito larvae were collected and morphologically identified as Culex pipiens. An average of $150 \mathrm{C}$. pipiens females mosquitoes from NAMRU 3 colony were assayed for each of the insecticides tested and control. C. pipiens strain was found to be fully susceptible to all of them by yielding $100 \%$ mortality after $24 \mathrm{~h}$ of observation and therefore confirmed the effectiveness of the insecticide-impregnated papers.

Two hundred females from each study area (Menofia, El Fayoum and Giza) were exposed to $0.05 \%$ lambda-cyhalothrin and 4\% DDT for 1 hour, and mortality were counted after 24 hours. The percentages of knocked-down mosquitoes after exposure 
to lambda-cyhalothrin for one hour were increased from $7 \%$ to $25 \%$, from $9 \%$ to $35 \%$ and from $13 \%$ to $55 \%$ at time intervals 15 and $60 \mathrm{~min}$. for Menofia, Giza and EL-Fayoum populations, respectively (Fig. 2). The percentages of knocked-down mosquitoes after exposure to DDT for one hour increased from $7 \%$ to $24 \%$, from $8 \%$ to $33 \%$ and from $12 \%$ to $53 \%$

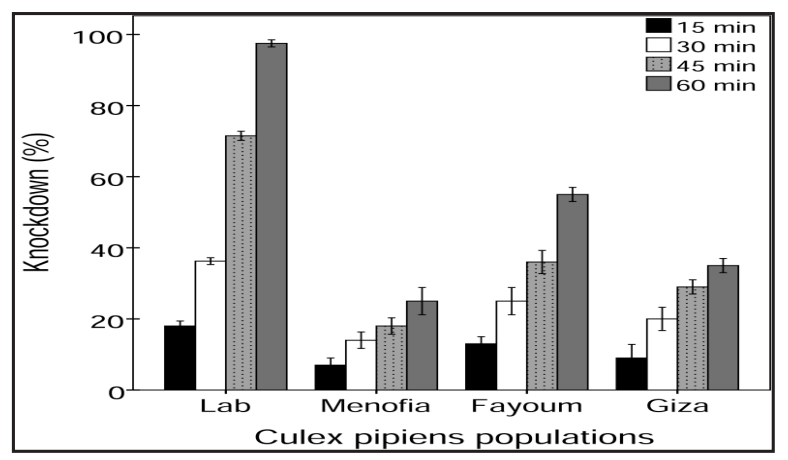

Fig. (2): Percentage Knockdown at four-time intervals of lab and three wild populations of Culex pipiens adults exposed to $0.05 \%$ Lambda-cyhalothrin. at time intervals 15 and $60 \mathrm{~min}$. for Menofia, Giza and EL-Fayoum populations, respectively (Fig. 3). Twenty-four-hour percentage mortalities were $43 \%$, $50 \%$ and $89 \%$ for lambda-cyhalothrin and $40 \%, 48 \%$ and $81 \%$ for DDT (Table, 1 and Fig. 4) for Menofia, Giza and EL-Fayoum populations, respectively.

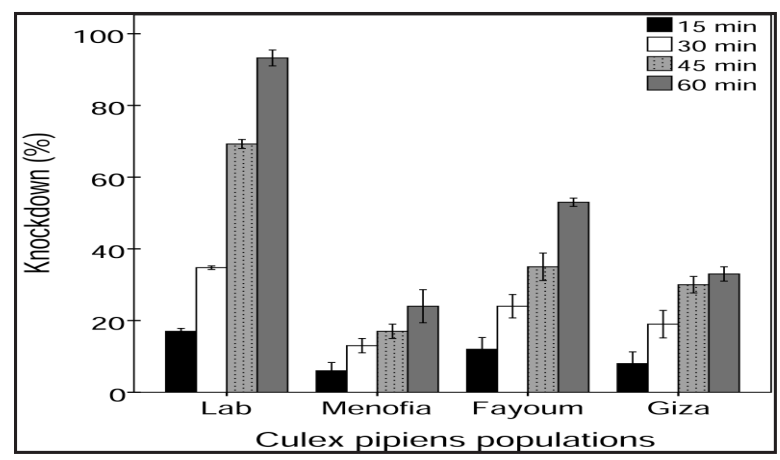

Fig. (3): Percentage Knockdown at four-time intervals of lab and three wild populations of Culex pipiens adults exposed to $4 \%$ DDT.

Table (1) : Percentage mortalities of lab and three wild populations of Culex pipiens adults under laboratory conditions after one-hour exposure to $0.05 \%$ Lambda-cyhalothrin and 4\% DDT.

\begin{tabular}{|c|c|c|}
\hline \multirow{2}{*}{ Population } & \multicolumn{2}{|c|}{ Insecticide } \\
\cline { 2 - 3 } & $\mathbf{0 . 0 5 \%}$ Lambda-cyhalothrin & $\mathbf{4 \%}$ DDT \\
\hline Lab & $100.0 \pm 0.0^{\mathrm{a}}$ & $100.0 \pm 0.0^{\mathrm{a}}$ \\
\hline Menofia & $43.0 \pm 1.9^{\mathrm{b}}$ & $40.0 \pm 1.6^{\mathrm{b}}$ \\
\hline Fayoum & $89.0 \pm 1.0^{\mathrm{c}}$ & $81.0 \pm 34^{\mathrm{c}}$ \\
\hline Giza & $50.0 \pm 2.0^{\mathrm{d}}$ & $48.0 \pm 1.6^{\mathrm{b}}$ \\
\hline
\end{tabular}

- Data are presented as mean $\pm S E$ of four replicates.

- Means followed by the same letter within each column are not significantly different (analysis of variance [ANOVA];

Tukey test; $P>0.05)$.

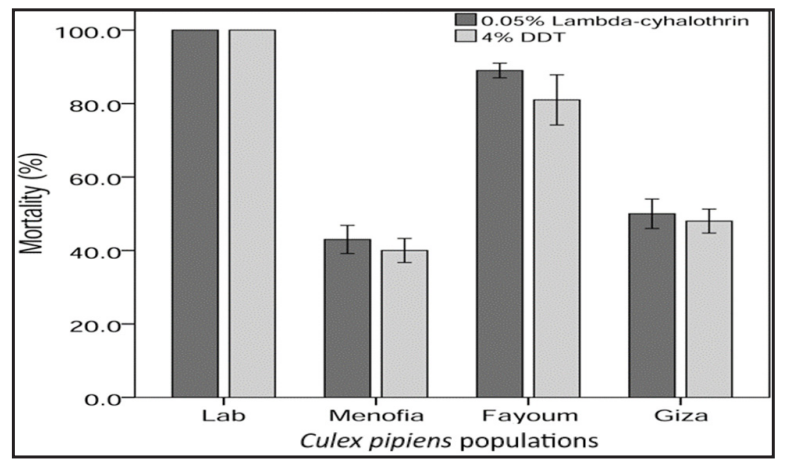

Fig. (4): Percentage mortalities of lab and three wild populations of Culex pipiens adults under laboratory conditions after one-hour exposure to $0.05 \%$ Lambdacyhalothrin and $4 \%$ DDT.

\section{DISCUSSION}

Insecticide application is the most efficient component in the global mosquito vector control effort (Zaim et al., 2000; Najera \& Zaim, 2001 and McCarroll \& Hemingway, 2002). Pyrethroids are currently the most widely worldwide used insecticides for insect pest control and human disease vectors. Insecticide resistance is a major concern in controlling vector borne diseases, especially in the tropical regions. Accurate monitoring of the resistance status is crucial to guide the rational application of insecti- 
cides and resistance management.

According to the WHO criteria (WHO, 2013), the present study demonstrated that $C$. pipiens populations from El-Fayoum, Menofia and Giza are resistant to Lambda-cyhalothrin (pyrethroids) and DDT (organochlorine) with variation in the resistance levels, ranging from the highest resistance and lowest mortality in Menofia to the lowest resistance and highest mortality in El-Fayoum.

Resistance of $C$. pipiens mosquitoes to pyrethroids has been reported in many countries such as China, ( Liu et al., 2013), Egypt (Zayed et al., 1997, Mostafa and Allam, 2001, Zayed et al., 2006, EISheikh, 2011 and EL-Sheikhet al., 2014), Greece (Kioulos et al., 2014), Japan (Kasai et al., 2009), Korea (Shin et al., 2012), La Reunion (Tantely et al., 2010), Mauritius (Pocquet et al., 2013), Mayotte (Pocquet et al., 2014), Saudi Arabia (Al-Sarar, 2010), and the United States (Ahmed et al., 2012).

The field population collected from EL-Fayoum displayed low level of resistance to lambda-cyhalothrin. In a similar study, $C$. pipiens field strain from Saudi Arabia, Riyadh. Two populations from Wadi Namar (WN1 and WN2) were highly resistant to deltamethrin, while the field population from Al-Wadi district showed low resistance to lambda-cyhalothrin (Al-Sarar, 2010). This was also reported in C. quinqefasciatus field strain from Brazil (Gonza' lez et al., 1999) and Malaysia (Nazni et al., 2005). In addition, resistance was detected in Ae. agypti populations to Lambda-cyhalothrin in India (Sharma et al., 2004) and in Saudi Arabia (Al-sheikh et al., 2016).

The present results are in consistence with Zayed et al. (2006) who found that adults $C$. pipiens collected from Qalubiya, Sharkiya and Assiut governorates, Egypt were resistant to DDT, but not to Lambda-cyhalothrin. The present findings regarding the low resistance of El-Fayoum population to lambda-cyhalothrin (pyrethroids), is contradicting with that of Mostafa and Allam (2001), who found that
C. pipiens adults from El-Fayoum were susceptible to deltamethrin (pyrethroids).

During this study, DDT resistance was observed in all sites. DDT has not been used in Egypt since the 1970s (Zayed et al., 2006) because high levels of resistance to DDT is not clear. This might be due to that both Pyrethroids and DDT act on the nervous system, and pyrethroid resistance might be associated with cross-resistance of DDT (Hemingway and Ranson, 2000). Cross-resistance between DDT and Pyrethroids has been reported previously in several locations throughout the world. FonsecaGonzález, et al. (2009) reported resistance to lambda-cyhalothrin and DDT among the same population in Colombia despite that fact that DDT was not used recently but 17 years before being replaced by lambda-cyhalothrin for malaria control.

The present results showed that populations from El-Fayoum, Menofia and Giza Governorates (agricultural areas) were resistance to pyrethroids. This might be due to the intensive use of pyrethroids to control agricultural pests in those areas, as previously suggested by Zayed et al. (2006). Coordination between health and agricultural sectors in terms of insecticide judicial use is highly recommended to avoid unpredictable development of insecticide resistance in vector populations.

\section{REFERENCES}

- Ahmed, M.A. I.; Cornel, A. and Hammock, B. (2012): Monitoring of Insecticide Resistance of Culex pipiens (Diptera: Culicidae) Colonies-Collected from California. Int. J. Environ. Sci. Technol, Vol. 3, No. 4.

- Al-Sarar, A.S. (2010): Insecticide resistance of Culex pipiens (L.) populations (Diptera:Culicidae) from Riyadh city, Saudi Arabia: status and overcome. Saudi $J$. Biol. Sci., 17: 95.

- Al-sheikh, A.A.; Mohamed, W.S.; Noureldin. E.M.; Daffalla, O.M.; Shrwanii. Y.A.; Hobani, K.J.; Alsheikh, F.A.; Alzahrani, M.H. and Binsaeed, A.A. (2016): Studies on Aedes aegypti Re- 
sistance to some insecticides in the Jasan District, Saudi Arabia. J. Egypt. Soc. Parasitol. (JESP), 46(1): 209.

- Centers for Disease Control and Prevention (CDC). (2002): Provisional surveillance summary of the West Nile Virus epidemic- US. Morb. Mort. Week. Rep., 51: 1129.

- Chapman, H. C. and Barr, A. R. (1969): Techniques for successful colonization of many mosquito species. Mosquito News, 25:532.

- Cui, F.; Lin, L.F.; Qiao, C.L.; Xu, U.; Marquine, M.; Weill, M.; and Raymond, M. (2006): Insecticide resistance in Chinese populations of the Culex pipiens complex through esterase overproduction. Entomol. Exp. Appl., 120: 211. 801e18b4

- Davidson, G. and Zahar, A.R. (1973): The practical implications of resistance of malaria vectors to insecticides. Bull World Health Organ; 49: 475.

- EL-Sheikh, E. A. (2011): Larval susceptibility Culex pipiens L. Diptera: Culicidae, collected from different localities at Sharkia governorate to some insecticides. Zagazig J. Agric. Res., 38:759.

- EL-Sheikh, E.A.; Mohamed-Bassem, A.; Ashour, M.A.; Amir, M.M. and Gamal, M.M. (2014): Monitoring the effect of insecticide selection on Culex pipiens (Diptera: Culicidae) larval susceptibility to malathion and lambda-cyhalothrin. $J$ Entomol, 11(1):14.

- Fonseca-González, I.; Quiñones, ML. McAllister, J. and Brogdon, W.G. (2009): Mixed-function oxidases and esterases associated with cross-resistance between DDT and lambda-cyhalothrin in Anopheles darlingi Root 1926 populations from Colombia. Mem Inst Oswaldo Cruz., 104: 18.

- Gonza' lez, T.; Bisset, J.A.; Dı'az, C.; Rodri'guez, M.M. and Brandolini, M. B. (1999): Insecticide resistance in a Cx. quinquefasciatus strain from Rio de Janeiro, Brazil. Mem. Inst. Oswaldo Cruz, Rio de Janeiro., 94 (1), 121.

- Harbach, R.E. (1985) Pictorial keys to the genera of mosquitoes, subgenera of Culex and the species of Culex
(Culex) occurring in southwestern Asia and Egypt, with a note on the subgeneric placement of Culex deserticola (Diptera: Culicidae). Mosquito Systematics, 17, 83.

- Hemingway, J. and Ranson, H. (2000): Insecticide resistance in insect vectors of human disease. Anпu. Rev. Entomol, 45: 371.

- Hemingway, J.; Beaty, B. J.; Rowland, M.; Scott, T. W. and Sharp, B. L. (2006): The Innovative Vector Control Consortium: improved control of mosquitoborne diseases. Trends Parasitol., 22(7):308.

- Kasai, S.; Komagata, O.; Tomita, T.; Sawabe, K.; Tsuda, Y.; Kurahashi, H.; Ishikawa, T.; Motoki, M.; Takahashi, T.; Tanikawa, T.; Yoshida, M.; Shinjo, G.; Hashimoto, T.; Higa, Y. and Kobayashi, M. (2008): PCR-based identification of Culex pipiens complex collected in Japan. Japanese J. Infect. Dis.,61: 184.

- Kasai, S.; Ishii, N.; Natsuaki, M.; Fukutomi, H.; Komagata, O. and Kobayashi, M. (2009): Prevalence of $k d r$-like mutations associated with pyrethroid resistance in human head louse populations in Japan. J. Med. Entomol., 46: 77.

- Katsuda,Y.; Leemingsawat, S.; Thongrungkiat, S.; Prummonkol, S.; Samung, Y.; Kanzaki, T.; Watanabe, T. and Kahara, T. (2008): Control of mosquito vectors of tropical infectious diseases: (2) pyrethroid susceptibility of Aedes aegypti (1) collected from different sites in Thailand. Southeast Asian J Trop Med Public Health, 39(2):229.

- Kioulos, I.; Kampouraki, A.; Morou, E.; Skavdisc, G. and Vontas, J. (2014): Insecticide resistance status in the major West Nile virus vector Culex pipiens from Greece. Pest Manag. Sci., 70: 623.

- Liu, H.; Lu, Y.; Liu, Q.; Huo, X.; Peng, B. and Ren, D. (2013): Comparison of pyrethroid resistance in adults and larvae of Culex pipiens pallens (Diptera: Culicidae) from four field populations in China. J. Econ. Entomol., 106: 360 .

- McCarroll, L. and Hemingway, J. (2002): Can insecticide resistance status affects parasite transmission in mosquitoes? Insect Biochem Mol Biol, 32: 1345. 
- Mostafa, A.A. and Allam, K.A. (2001): Studies on the present status of insecticides resistance on mosquitoes using the diagnostic dosages in El-Fayium Governorate, a spot area of malaria in Egypt. J Egypt Soc Parasitol, 31(1): 177.

- Najera. J.A. and Zaim. M. (2001): "Malaria vector control: insecticides for indoor residual spraying". In WHO document WHO/CDS/WHOPES, WHO, Geneva, pp. 3.

- $\quad$ Nazni, W.A.; Lee, H.L. and Azahari, A. H. (2005): Adult and larval insecticide susceptibility status of $C x$. quinquefasciatus (Say) mosquitoes in Kuala Lumpur Malaysia. Trop. Biomed., 22:63.

- $\quad$ Pocquet, N.; Milesi, P.; Makoundou, P.; Unal, S.; Zumbo, B. and Atyame, C. (2013): Multiple insecticide resistances in the disease vector Culex. quinquefasciatus from Western Indian Ocean. PLOS, ONE 8: e77855.

- $\quad$ Pocquet, N.; Darriet, F.; Zumbo, B.; Milesi, P.; Thiria, J. and Bernard, V. (2014): Insecticide resistance in disease vectors from Mayotte: an opportunity for integrated vector management, Parasit. Vectors, 7: 299.

- $\quad$ Rivero, A; Vezilier, J.; Weill, M.; Read, A.F. and Gandon, S. (2010): Insecticide control of vector-borne diseases: when is insecticide resistance a problem. PLoS Pathog., 6(8): e1001000.

- Sharma, S.N.; Saxena, V.K. and Lal, S. (2004): Study on susceptibility status in aquatic and adult stages of Aedes aegypti and Ae. albopictus against insecticides at international airports of south India. J. Commun. Dis. 36, $3: 177$.

- $\quad$ Shin, E.H.; Kim, N. J.; Kim, H.K.; Park, C.; Lee, D.K. and Ahn, Y.J. (2012): Resistance of field-collected populations of Culex pipiens pallens (Diptera: $\mathrm{Cu}-$ licidae) to insecticides in the Republic of Korea, J. Asia Pac. Entomol., 15: 1.

- $\quad$ SPSS Statistics (2008): SPSS Statistics software for windows, release 17.0. SPSS Statistics, Chicago, IL.

- Tantely, M.L.; Tortosa, P.; Alout, H.; Berticat, C.; Berthomieu, A.; Rutee, A.; Dehecq, J.S.; Makoundou, P.; Labbé, P.; Pasteur, N. and Weill, M. (2010): Insecticide resistance in Culex pipiens quinquefasciatus and Aedes albopictus mosquitoes from La Reunion Island. Insect Biochem. Mol. Biol., 40: 317.

- Tungu, P.; Magesa, S.; Maxwell, C.; Malima, R.; Masue, D.; Sudi, W.; Myamba, J.; Pigeon, O. and Rowland, M. (2010): Evaluation of PermaNet 3.0 a deltamethrin-PBO combination net against Anopheles gambiae and pyrethroid resistant Culex quinquefasciatus mosquitoes: an experimental hut trial in Tanzania. Malaria J., 9(1):21.

- World Health Organization WHO (1981a): Instructions for determining the susceptibility or resistance of adult mosquitoes to organochlorine, organophosphates and carbamate insecticides establishment of the baseline. WHO/VBC/81.805. http://www. who.int/home.

- World Health Organization (WHO). (1998): Test procedures for insecticide resistance monitoring in malaria vectors, bio-efficacy and persistence of insecticides on treated surfaces. Report of the WHO informal consultation. Geneva: WHO., 28. http://www.who.int/home.

- World Health Organization. (2009a): Global Insecticide Use for Vector-Borne Disease control- 4th edition. In: WHO/HTM/NTD/WHOPES/ GCDPP/20096. Geneva, Switzerland: 82. http://www. who.int/home.

- World Health Organization. (2009b): Guidelines for efficacy testing of insecticides for indoor and outdoor ground applied space spray applications. WHO, Geneva, Switzerland. http://www.who.int/home.

- World Health Organization. (2013): Test procedures for insecticide resistance monitoring in malaria vector mosquitoes. VCU. GMP, WHO, Geneva, Switzerland. http://www.who.int/home.

- Zahran, H.E.D.M. and Abdelgaleil, S.A.M. (2011): Insecticidal and developmental inhibitory properties of monoterpenes on Culexpipiens L. (Diptera: Culicidae). J. Asia-Pacific Entomol., 14: 46.

- Zaim, M.; Aitio, A. and Nakashima, N. (2000): Safety of pyrethroid-treated mosquito nets. Med. Vet. Entomol., 14(1):1.

- Zayed, A.B.; Mostafa, A.A.; Osman, M.Z. and Kotb N.A. (1997): Susceptibility of Culexpipiens complex 
mosquito to some insecticides in Egypt. Al-Azhar Bull. Sci., 8: 223.

- Zayed, A. B.B.; Szumlas, D.E.; Hanafi, H.A.; Fryauff, D.J.; Mostafa, A.A.; Allam, K. M. and Brogdon, W.

G. (2006): Use of bioassay and microplate assay to detect and measure insecticide resistance in field populations of Culex pipiens from filariasis endemic areas of Egypt. J Am Mosq Control Assoc Suppl, 22(3): 473.

- Zhang, H.; Meng, F.; Qiao, C. and Cui, F. (2012): Identification of resistant carboxylesterase alleles in $\mathrm{Cu}$ lex pipiens complex via PCR-RFLP. Parasit. Vectors, 5(1):209. 
رصد مقاومت Pyrethroid في تجمعات البعوض Culex pipiens من ثلاث محافظات مصربم

ربهام تاج الدين' ـ عاليتت زايدّ وامتثال عبد السميع' وهناء إبراهيم' وعبد الباسط زايد'

مراقبت مقاومت المبيدات الحشريت المستخدمت فى مكافحت البعوض أمر بالغ الأهميت على حد سواء تعدد مستويات وآليات المقاومت أمر هام لتحديد كفاءة المبيدات لمكافحت ناقلات الأمـراض. وقد تم اختبار المبيد LDT Lambda-cyhalothrin ملى بعوض Culex pipiens التي تم جمعها من ثلاث محافظات مختلفت يْ مصر (الفيوم والمنوفيت والجيزة). وأظهرت النتائج مقاومته ملحوظت لهذه المبيدات الحشريت التي تم اختبارها بين البعوض المجمـع من المنوفيت والجيزة ، يِّ حين أظهر البعوض الذي تم تجميعه من الفيوم العكس. وهذا قد يكون جرس انذار لعدم استخدام نفس المبيدات للمكافحت فى هذه المناطق • على الجانب الأخر تشيد بالقطاعات الصحيت ومتخذلي القرار لمكافحت ناقلات الأمراض ان برامـج مكافحت البعوض قد تحتاج إلى النظر ٌِِ مبيدات حشرات بديلت ل Culex pipiens هٍِ المناطق التي يتهم رصدها. 
